\title{
Özofagus Cerrahisi Sonrası Gelişen Candida hellenica Kandidemisi
}

\section{Candida hellenica Candidemia Occurred After Esophagus Surgery}

\author{
Ufuk ATEŞ⿻コ一ㄴ. \\ ${ }_{1}^{1}$ Ankara Üniversitesi Tıp Fakültesi, Çocuk Cerrahisi Bilim Dalı, Ankara \\ ${ }^{1}$ Ankara University Faculty of Medicine, Department of Pediatric Surgery, Ankara, Turkey. \\ 2 Gazi Üniversitesi Tıp Fakültesi, Tıbbi Mikrobiyoloji Anabilim Dalı, Ankara. \\ ${ }^{2}$ Gazi University Faculty of Medicine, Department of Medical Microbiology, Ankara, Turkey.
}

Makale Atıfı: Ateş U, Gurbanova A, Yiğitoğlu FN, Kalkancı A. Özofagus cerrahisi sonrası gelişen Candida hellenica kandidemisi. Mikrobiyol Bul 2020;54(2):334-338.

\section{ÖZ}

$\mathrm{Bu}$ olgu raporunda Candida hellenica kaynaklı kandidemi olgusu sunulmuştur. Yirmi yaşında erkek hastaya Ekim 2018 tarihinde özofagus operasyonu sonrasında kandidemi tanısı nedeniyle flukonazol ve lipozomal amfoterisin B tedavisi başlanmıştır. Hastanın geçmişte çok sayıda özofagus operasyonu öyküsü bulunmaktadır. Tedaviyi takiben son 24 saat içinde ateşi olmaması, genel durumunun düzelmesi ve kan kültürlerinde üreme olmaması nedeniyle hasta taburcu edilmiştir. Kan kültüründe üreyen Candida izolatının çimlenme borusu testi negatif, mısır unu-tween 80 agardaki morfolojisi tanımlayıcı bulunmamıştır. Hasta izolatı karbonhidrat asimilasyonu temelli ID32 ${ }^{\circledR}$ (bioMérieux, Fransa) yönteminden elde edilen profile göre C.hellenica olarak tanımlanmıştır. Tür tanımlamasının doğrulanması amacıyla rRNA üzerindeki hedef ITS gen bölgeleri uygun primerler kullanılarak polimeraz zincir reaksiyonu ile çoğaltılmış ardından dizi analizi yapılmıştır. Elde edilen DNA dizileri "National Center for Biotechnology Information (BLAST)" sistemi (http://www.ncbi.nlm.nih.gov/BLAST/) kullanılarak gen kütüphanesi kayıtları ile karşılaştırılmış ve \%99 uyumla C.hellenica olarak tanımlanmıştır. Maya tanımlaması MALDI-TOF (Vitek MS, bioMerieux) ile yapılamamıştır. Antifungal duyarlılığın test edilmesi amacıyla "Clinical and Laboratory Standards Institute" önerilerine uygun olarak referans mikrodilüsyon yöntemi gerçekleştirilmiştir. Minimum inhibitör konsantrasyonu değerleri 24 saat inkübasyon sonrasında amfoterisin B, flukonazol, vorikonazol ve itrakonazol için sırasıyla $0.25 \mu \mathrm{g} / \mathrm{ml}, 8 \mu \mathrm{g} / \mathrm{ml}, 0.25 \mu \mathrm{g} / \mathrm{ml}, 0.25 \mu \mathrm{g} / \mathrm{ml}$ olarak bulunmuştur. Olgumuz gastrointestinal sistem operasyonu öyküsü olan bir hasta olması nedeniyle, kandideminin endojen kaynağının mukozal yapının bozulmasına bağlı gastrointestinal sistem olduğu ve bu hasarın Candida'nın yayılımını kolaylaştırdığı düşünülmüştür. Kandidemi etkeninin tür düzeyinde tanımlanmasında kullanılan karbonhidrat asimilasyon testi, ID32 ${ }^{\circledR}$ ile bu olguda tanımlama yapılabilmiştir. Ancak, yaygın olmayan veya daha önceden tanınmayan organizmalar ticari sistemler tarafından yanlış tanımlanabilmektedir. Rutin mikrobiyolojide fenotipik tanımlama yeterli bulunurken, bu olguda olduğu gibi mikroorganizmanın tür tanımlamasının DNA dizi analizi ile kesinleştirilmesi zorunludur. Bu olgu raporunda, etkenin tür tanımlaması yapılarak kandidemi tanısı alan ve sonrasında antifungal tedavi ile iyileşen bir olgu 
sunulmuştur. Bu olguda kandidemi mortal seyretmemiş olmakla birlikte, kandidemi mortalitesinin \%50 olduğu unutulmamalıdır. Literatürde bir kandidemi, bir solunum yolu kolonizasyonu olgusu olmak üzere, toplam iki C.hellenica enfeksiyonu bildirilmiştir. Başarılya tedavi edilmiş olan olgumuz bu nadir etkene dikkat çekmek üzere sunulmuştur.

Anahtar kelimeler: Kandidemi; Candida hellenica; özofagus cerrahisi.

\section{ABSTRACT}

In this study, a case of candidemia caused by Candida hellenica as the first report in our country was presented. Fluconazole and liposomal amphotericin B treatment was initiated in a 20-year-old male patient in October 2018 due to the diagnosis of candidemia following esophageal surgery. The patient had a history of multiple esophageal operations. The patient was discharged during the last 24 hours due to the lack of fever, improvement in general condition and lack of growth in blood cultures. Germination tube test of the Candida isolate grown in blood culture was negative and the colony morphology in corn meal tween 80 agar was not defining. It was identified as C.hellenica according to the profile obtained from the ID32C ${ }^{\circledR}$ (bioMérieux, France) method based on carbohydrate assimilation. The target ITS regions of the rRNA genes were amplified by polymerase chain reaction and sequenced using suitable primers for the confirmation of the identification on species level. The DNA sequences obtained were searched by using the "National Center for Biotechnology Information (BLAST)" (http://www.ncbi.nlm.nih.gov/ BLAST/) database and the isolate was identified as C.hellenica with a $99 \%$ homology with GenBank sequences. MALDI-TOF (Vitek MS, bioMerieux) could not identify the yeast isolate. The reference microdilution method was performed according to the recommendations of the Clinical and Laboratory Standards Institute in order to test the antifungal susceptibility. The minimal inhibitory concentrations for the isolate, determined after 24-hour incubation were $0.25 \mu \mathrm{g} / \mathrm{ml}$ for amphotericin B, $8 \mu \mathrm{g} / \mathrm{ml}$ for fluconazole, $0.25 \mu \mathrm{g} / \mathrm{ml}$ for voriconazole, and $0.25 \mu \mathrm{g} / \mathrm{ml}$ for itraconazole. As our case had a previous history of gastrointestinal tract surgery it was thought that gastrointestinal tract was the endogenous source of candidemia by leading to mucosal disruption and this mucosal disruption might facilitate the translocation of Candida. The carbohydrate assimilation test ID $32 \mathrm{C}^{\circledR}$, was able identify the causative agent of candidaemia at the species level in this case. However, uncommon or previously unrecognized organisms may be misidentified by commercial systems. While the phenotypic definition is sufficient in routine laboratories, it is mandatory to confirm the microorganism species definition by DNA sequence analysis, as done in this case. We have presented a correctly identifed and successfully treated candidemia case. Although the candidemia was not mortal in our patient, the mortality rate of candidemia which is $50 \%$, should be remembered. A total of two C.hellenica infections have been reported in the literature, including one candidaemia and one respiratory tract colonization. Our successfully treated case was presented to draw attention to this rare infectious agent.

Keywords: Candidemia; Candida hellenica; esophagus surgery.

\section{Giriş}

Candida türleri sağlık hizmeti ile ilişkili kan dolaşımı enfeksiyonlarının etkeni olarak son 20 yıldır giderek artan sıklıkta karşımıza çıkmaktadır. En sık Candida albicans türü etken olmakla birlikte, azollerin kullanımının artmasıyla diğer türlerin sıklığı da giderek artmaktadır $^{1,2}$. Kan kültüründe üreyen etkenin tür düzeyinde doğru tanımlanması ve antifungal duyarlılık özelliklerinin ortaya çıkarılması doğru tedavinin başlanması için zorunludur. Candida'ların tür düzeyinde tanımlanması için çimlenme borusu testi, mısır unu-tween 80 agarda oluşan morfolojik özellikleri, karbonhidrat asimilasyon özelliklerine göre çalışan ID32C ve API20C gibi yarı otomatize sistemler, son yıllarda kullanıma giren proteomik tanımlamaya dayalı "Matrix-assisted laser desorption/ionization-time-of-flight mass 
spectrometer (MALDI-TOF)" bulunmaktadır. Rutin laboratuvarlarda bu sistemler tanımlama için yeterli kabul edilmekle birlikte, tür tanımlamasının doğrulanması rRNA geni üzerindeki ITS bölgesinin dizi analizi ile gerçekleşmektedir ${ }^{3}$.

Kandidemi gelişen hastalarda mortalite ile ilişkili risk faktörleri olarak santral venöz kateter varlığı, antibiyotik kullanımı, gastrointestinal sisteme yönelik uygulanan cerrahi işlemler, nötropenik durum ve yoğun bakım ünitesinde yatış öyküsü bulunmaktadır ${ }^{4}$.

Bu raporda, Ankara Üniversitesi Tıp Fakültesi Hastanesi Çocuk Cerrahisi Kliniğinde yatan, özofagostomi cerrahi revizyonları geçirmiş bir hastada C.hellenica ile gelişen kandidemi olgusu sunulmuştur.

\section{OLGU SUNUMU}

Bu olgu raporunda, Ekim 2018 tarihinde özofagostomi bölgesinde gelişen fistüllerin onarımı amacıyla yapılan özofagostomi revizyonları sırasında ateşi yükselen 20 yaşında erkek hasta sunulmaktadır. İki buçuk yaşında çamaşır suyu içme öyküsü bulunan hasta 11 yaşındayken disfaji gelişmesi üzerine endoskopi takipleri sonrasında dilatasyon amacıyla gastrointestinal sistem cerrahisi işlemleri geçirmiştir. Son yapılan özofagus revizyonu sonrasında ateşinin yükselmesi nedeniyle alınan kan kültüründe tür düzeyinde tanımlanamayan bir Candida üremesi nedeniyle hastaya flukonazol ve lipozomal amfoterisin B tedavisi başlanmıştır. Ardışık iki kan kültüründe aynı etken üretilmiştir. Tedavi devam ederken hastanın ateşi düşmüş, genel durumu düzelmiş ve 28 Ekim 2018 tarihinde kan kültürlerinde üreme olmaması nedeniyle taburcu edilmiştir. Kan kültüründe üreyen Candida izolatı, tür tanımlaması amacıyla Gazi Üniversitesi Tıp Fakültesi Tıbbi Mikrobiyoloji Laboratuvarına gönderilmiştir. Tanımlama amacıyla yapılan çimlenme borusu testi negatif saptanırken, mısır unu-tween 80 agardaki morfolojisi tanımlayıcı bulunmadı. İzolat, karbonhidrat asimilasyonu temelli ID32 $C^{\circledR}$ (bioMérieux, Fransa) yöntemi ile C.hellenica olarak tanımlandı (7571/7742/57; \%ID 99.9). MALDI-TOF (Vitek MS, bioMerieux) yöntemi ile maya tanımlaması yapılamadı. Antifungal duyarlılığın test edilmesi amacıyla "Clinical and Laboratory Standards Institute (CLSI)" önerilerine uygun şekilde L-glutaminli RPMI 1640 kullanılarak referans mikrodilüsyon yöntemi uygulandı. Minimum inhibitör konsantrasyonu (MiK) değerleri 24 saat inkübasyon sonrasında amfoterisin B, flukonazol, vorikonazol, itrakonazol için sırasıyla $0.25 \mu \mathrm{g} / \mathrm{ml}, 8 \mu \mathrm{g} / \mathrm{ml}, 0.25 \mu \mathrm{g} / \mathrm{ml}$ ve $0.25 \mu \mathrm{g} / \mathrm{ml}$ olarak bulundu.

Tür tanımlamasının doğrulanması amacıyla kültürde üreyen kolonilerden genomik DNA izole edilerek rRNA üzerindeki ITS gen bölgesine yönelik dizi analizi yapıldı. ITS1 5'-CTT GGT CAT TTA GAG GAAGTA-3' ve ITS4 5'-TCC TCC GCT TAT TGA TAT GC3' primerleri kullanıldı. Polimeraz zincir reaksiyonu (PCR) ürünleri BigDye ${ }^{\circledR}$ Terminator Cycle Sequencing Ready Reaction kit (Perkin Elmer, Türkiye) kullanılarak boyandıktan sonra, ddNTP ile işaretli örneklere ABI PrismTM 310 Genetic Analyzer (Applied Biosystems, ABD) cihazında kapiller elektroforez uygulandı. Hem ITS1 hem de ITS4 primerleri ile iki kez dizileme yapıldı. Elde edilen DNA dizileri "National Center for Biotechnology Information" BLAST sistemi (http://www.ncbi.nlm.nih.gov/BLAST/) kullanılarak gen kütüphanesi kayıtları ile karşılaştırıldı ve \%99 uyumla Candida hellenica olarak tanımlandı. 


\section{TARTIŞMA}

Kandidemi en sık C.albicans türü ile gelişen kan dolaşımı enfeksiyonudur. Diğer türler kandidemi olgularının yaklaşık \%50'sini oluşturur ${ }^{5}$. Bu çalışmada, C.hellenica üreyen kandidemi olgusu sunulmaktadır. Bildiğimiz kadarıyla, bu olgu ülkemizden bildirilen ilk C.hellenica kandidemisi olgusudur.

C.hellenica türü Zygoascus cinsi içinden ayrılan bir türdür. Zygoascus cinsinin telemorfik formu (seksüel = eşeyli) 1986 yılında Maudy Th. Smith tarafından tanımlanmıştır. Bu cins içinden üç anamorfik (aseksüel = eşeysiz) tür; C.hellenica, Candida inositophila ve Candida steatolytica ayrılmıştır6. Daha sonra Zygoascus hellenicus ve Zygoascus meyerae sp. nov. olmak üzere iki yeni telemorfik tür tanımlanmıştır. C.steatolytica var. steatolytica ve C.steatolytica var. inositophila türleri Z.hellenicus ile, C.hellenica var. hellenica ve C.hellenica var. acidophila türleri ise Z.meyerae ile bağlantılı bulunmuştur ${ }^{7,8}$.

Literatürde Z.hellenicus'un (anamorfu C.hellenica) çürük üzümlerden, bir sığır mastiti olgusundan ve çevresel kaynaklardan izole edildiği bildirilmiştir. İnsanlarda enfeksiyon etkeni olarak iki olguda C.hellenica bildirimi bulunmaktadır ${ }^{8,9}$. Bunlardan ilki, allojeneik kök hücre nakli alıcısı olan bir hastada gelişen fungemi sonrası tanımlanmıştır. Bu olguda mayayı tanımlamak için öncelikle API20C kullanılmış ve yanlış bir şekilde Candida ciferri olarak tanımlanmıştır. DNA dizi analizinden sonra \%99 uyumla Z.hellenicus olarak tanımlanmıştır.Tanımlamayı doğrulamak amacıyla başka bir merkeze gönderilen aynı izolat ID32C sistemi ile C.hellenica olarak tanımlanmıştır ${ }^{9}$. Ikinci olguda, etken akut miyeloid lösemili bir çocuk hastada gelişen solunum yolu enfeksiyonu sırasında solunum yolu örneğinde üretilmiştir. Enfeksiyon etkeni olarak değil, kolonizasyon olarak düşünülmüştür. Bu merkezde yapılan tanımlamada ID32C kullanılmış ve C.hellenica olarak tanımlanmıştır. Tanımlamayı doğrulamak amacıyla ITS dizi analizi de yapılmış ve tanımlama moleküler olarak doğrulanmıştır ${ }^{8}$. Olgumuzda rutinde kullanılan ID32C sistemi etkeni C.hellenica olarak tanımlamıştır. Literatürdeki iki olgu ve olgumuzun tür düzeyinde tanımlanmasında ID32C sistemi yeterli ve doğru tanımlamayı yapabilmiştir.

Yaygın olmayan veya daha önceden tanınmayan organizmalar ticari sistemler tarafından yanlış tanımlanabilmektedir. C.hellenica, API20C veri tabanında olmayıp, ID32C veri tabanında bulunmaktadır. Fenotipik olarak karbonhidrat asimilasyon özelliklerini kullanan API20C, ID32C gibi sistemlerin veri tabanları güncellenmediği zaman, tür tanımlamalarında yanıltıcı olabilmektedir ${ }^{10,11}$. Rutinde fenotipik tanımlama yeterliyken, olgu bildirimi yapılacak ise, mikroorganizma tür tanımının DNA dizi analizi ile kesinleştirilmesi zorunludur. Bizim olgumuzda ve diğer iki olguda C.hellenica tür tanımı DNA dizi analizi ile doğrulanmıştır.

Olgumuz gastrointestinal sistem cerrahisi geçirmiş bir hastadır. Kandideminin kaynağı her zaman önemli bir tartışma konusu olmuştur. Nucci ve arkadaşları ${ }^{12}$ bu konuya açıklık getirebilmek için 1966-2000 yılları arasında yayımlanmış çalışmaları MEDLINE veritabanını kullanarak incelemiştir. Bu çalışma sonucunda gastrointestinal sistem, kandideminin 
önemli bir kaynağı olarak bulunmuştur. Gastrointestinal sistem cerrahisi sonrası sıklıkla gelişen bağırsak stazı Candida'nın aşırı çoğalmasına yol açmakta ve mukoza hasarının gelişmesi sonucu Candida'nın yayılımı kolaylaşmaktadır ${ }^{13}$. Hastalarda cerrahi sonrası gelişen enfeksiyonlarda Candida son yıllarda görülen etkenlerden biridir. Bu hastalarda kandidemi nedeniyle yatış süresi uzamakta, mortalite oranları yükselmektedir ${ }^{14}$. Olgumuz kandidemi sonrası antifungal tedavi ile iyileşen bir hastadır. Ancak, kandidemili hastalarda \%50 mortalite olabileceği akılda tutulmalıdır.

\section{ÇIKAR ÇATIŞMASI}

Yazarlar bu makale ile ilgili herhangi bir çıkar çatışması bildirmemişlerdir.

\section{KAYNAKLAR}

1. Diekema D, Arbefeville S, Boyken L, Kroeger J, Pfaller M. The changing epidemiology of healthcareassociated candidemia over three decades. Diagn Microbiol Infect Dis 2012; 73(1): 45-8.

2. Wisplinghoff H, Ebbers ], Geurtz L, Stefanik D, Major Y, Edmond MB, et al. Nosocomial bloodstream infections due to Candida spp. in the USA: species distribution, clinical features and antifungal susceptibilities. Int J Antimicrob Agents 2014; 43(1): 78-81.

3. Alıskan HE, Bozkırı ED, Çolakoğlu Ş, Demirbilek M. Evaluation of risk factors of Candida albicans and nonalbicans Candida candidemia in a tertiary-care hospital for three years. Turk Hij Den Biyol Derg 2016; 73(1): 15-24.

4. Erdem H, Erganiş S, Evren E, Aksakal FN, Çağlar K, Kalkancı A. Comparative analysis of different methods used for the identification of Candida on species level. Türk Mikrobiyol Cem Derg 2017; 47(3): 114-24.

5. Kazak E, Akın H, Ener B, Sığırlı D, Özkan Ö, Gürcüoğlu E, et al. An investigation of Candida species isolated from blood cultures during 17 years in a university hospital. Mycoses 2014; 57(10): 623-9.

6. Smith MT. Zygoascus hellenicus gen. nov., sp. nov., the teleomorph of Candida hellenica (= C.inositophila $=$ C.steatolytica). Antonie Van Leeuwenhoek 1986; 52(1): 25-37.

7. Smith MT, Robert V, Poot GA, Epping W, de Cock AW. Taxonomy and phylogeny of the ascomycetous yeast genus Zygoascus, with proposal of Zygoascus meyerae sp. nov. and related anamorphic varieties. Int I Syst Evol Microbiol 2005; 55(Pt 3): 1353-63.

8. Ioakimidou A, Vyzantiadis TA, Tragiannidis A, Arabatzis M, Papageorgiou T, Velegraki A, et al. Candida hellenica var. hellenica as a possible cause of respiratory infection in a child with acute myeloid leukemia. Med Mycol 2011; 49(7): 771-4.

9. Brandt ME, Kauffman CA, Pappas PG, lqbal N, Arthington-Skaggs BA, Lee-Yang W, et al. Fungemia caused by Zygoascus hellenicus in an allogeneic stem cell transplant recipient. J Clin Microbiol 2004; 42(7): 3363-5.

10. Hajjeh RA, Sofair AN, Harrison LH, Lyon GM, Arthington-Skaggs BA, Mirza SA, et al. Incidence of bloodstream infections due to Candida species and in vitro susceptibilities of isolates collected from 1998 to 2000 in a population-based active surveillance program. J Clin Microbiol 2004; 42(4): 1519-27.

11. Kao AS, Brandt ME, Pruitt WR, Conn LA, Perkins BA, Stephens DS, et al. The epidemiology of candidemia in two United States cities: results of a population-based active surveillance. Clin Infect Dis 1999; 29(5): 1164-70.

12. Nucci M, Anaissie E. Revisiting the source of candidemia: skin or gut? Clin Infect Dis 2001; 33(12): 195967.

13. Shan YS, Sy ED, Wang ST, Lee JC, Lin PW. Early presumptive therapy with fluconazole for occult Candida infection after gastrointestinal surgery. World J Surg 2006; 30(1): 119-26.

14. Ala-Houhala $M$, Valkonen $M$, Kolho E, Friberg $N$, Anttila VJ. Clinical and microbiological factors associated with mortality in candidemia in adult patients 2007-2016. Infect Dis (Lond) 2019; 51(11-12): 824-30. 